\title{
Edukasi Kebiasaan Cuci Tangan Pada Anak Sekolah sebagai Upaya Menurunkan Resiko Diare
}

\author{
Iwan Suhendar, Witdiawati \\ Fakultas Keperawatan, Universitas Padjadjaran \\ Email: witdiawati14001@unpad.ac.id
}

\begin{abstract}
Abstrak
Tangan merupakan salah satu agen utama masuknya kuman/mikroba penyebab penyakit, ke mulut, hidung dan anggota tubuh lainnya. Banyak masalah kesehatan yang dapat ditimbulkan dari kebiasaan cuci tangan salah satunya adalah Diare. Anak sekolah merupakan populasi yang rentan terkena penyakit diare. Tujuan pengabdian kepada masyarakat adalah kegiatan ini adalah mengidentifikasi pengetahuan pada anak usia sekolah tentang kebiasaan cuci tangan sebagai upaya menurunkan resiko diare di SDN 01 Jayaraga Kecamatan Tarogong Kidul. Metode pelaksanaan kegiatan program pengabdian masyarakat ini adalah penyuluhan kesehatan dan simulasi cuci tangan kepada anak sekolah, dengan peserta yang hadir 56 siswa kelas V SD, 2 orang guru, dan 6 orang mahasiswa. Kegiatan dimulai dari tahapan perencanaan, pelaksanaan dan evaluasi hasil kegiatan penyuluhan dengan menggunakan kuesioner. Hasil kegiatan ada perubahan signifikan dalam pengetahuan siswa. Berdasarkan hasil jawaban kuis dari 56 siswa didistribusi frekuensi dengan hasil pengetahuan sebelum penkes adalah $61 \%$ dalam kategori baik dan 39\% dalam kategori kurang, sedangkan untuk pengetahuan sesudah adalah 91\% dalam kategori baik. Kesimpulan sebagian besar pengetahuan siswa tentang kebiasaan cuci tangan sudah baik. Perlu optimalisasi peran guru, petugas kesehatan dan kader kesehatan sekolah untuk kontinuitas penerapan kebiasaan cuci tangan di sekolah.
\end{abstract}

Kata kunci : Cuci tangan, edukasi, siswa sekolah.

\begin{abstract}
The hand is one of the main agents of entry of germs / microbes that cause disease, into the mouth, nose and other limbs. Many health problems that can result from hand washing habits one of which is diarrhea. School children are a population vulnerable to diarrhea. The aim of community service is that this activity is to identify knowledge in school-age children about handwashing habits as an effort to reduce the risk of diarrhea in SDN 01 Jayaraga, Tarogong Kidul District. The method of implemented this community service program is health counseling and hand washing simulations to school children, with participants attended 56 fifth grade elementary school students, 2 teachers, and 6 students. The activities starts from the planning, implementation and evaluation stages of the resulted of the extension activities used a questionnaire. The resulted of activities there are significant changes in student knowledge. Based on the results of quiz answers from 56 students the frequency distribution with the results of knowledge before the health test was $61 \%$ in the good category and $39 \%$ in the poor category, while for the after knowledge was $91 \%$ in the good category. Conclusion most of the students' knowledge about hand washing habits is good. It is necessary to optimize the role of teachers, health workers and school health cadres for the continuity of the application of hand washing habits in schools.
\end{abstract}

Keywords : Education, hand washing, school students. 


\section{Pendahuluan}

Upaya promosi kesehatan pada anak sekolah salah satunya adalah melalui penerapan perilaku hidup bersih dan sehat (PHBS) disekolah. Perilaku hidup bersih sehat merupakan sebuah upaya untuk menularkan pengalaman mengenai pola hidup sehat melalui pemberdayaan individu, kelompok ataupun masyarakat luas dengan jalur komunikasi sebagai media berbagi informasi. Pendidikan kesehatan adalah kontribusi yang direncanakan atau direncanakan mulai dari pengalaman belajar berdasarkan teori dan disampaikan kepada individu, kelompok dan masyarakat yang bertujuan untuk meningkatkan kapasitas atau kapasitas dan kompetensi dalam membuat keputusan kesehatan (Glanz,et.al, 2008). WHO merumuskan promosi kesehatan sebagai suatu proses untuk meningkatkan kemampuan masyarakat untuk mempertahankan dan meningkatkan kesehatan mereka. Selain itu, untuk mencapai tingkat kesehatan yang sempurna, baik fisik, mental, dan sosial, masyarakat harus dapat mengenali, mewujudkan aspirasi mereka, kebutuhan mereka, dan mampu mengubah atau mengatasi lingkungan mereka (Depkes RI, 2014).

Cuci tangan merupakan salah satu perilaku sederhana yang penting untuk diterapkan mejadi kebiasaan dalam kehidupan sehari-hari. Tangan merupakan salah satu agen utama masuknya kuman/mikroba penyebab penyakit, ke mulut, hidung dan anggota tubuh lainnya. Penyebarannya bisa melalui makanan dan minuman atau benda-benda yang menempel ditangan baik secara sengaja atau tidak sengaja. Selain untuk diri sendiri tangan juga sebagai sumber penyaluran kuman dari satu orang ke orang lainnya. Banyak masalah kesehatan yang dapat ditimbulkan dari kebiasaan cuci tangan salah satunya adalah penyakit Diare (Depkes, 2014)

Integrasi perilaku hidup bersih dan sehat (PHBS) disekolah salah satunya dengan adanya indikator sekolah sehat seperti indikator fisik; 1) jumlah murid dengan status gizi normal; 2) memiliki sarana air bersih yang memadai dan jamban yang saniter mencukupi; 3) memiliki sarana cuci tangan dan tempat sampah yang mencukupi; 4) melakukan cuci tangan pakai sabun; 5) sarapan/makan siang dan sikat gigi bersama; 6) melakukan aktivitas fisik secara teratur; 7) melakukan penjaringan kesehatan dan pemeriksaan berkala. indikator mental meliputi: 1) memberikan pendidikan keterampilan hidup sehat (kompetensi psikososial) di sekolah, dan sosial; 1) wilayah ktr (kawasan tanpa rokok); 2) wilayah ktn (kawasan tanpa narkoba); 3) wilayah ktk (kawasan tanpa kekerasan); 4) mempunyai kader kesehatan sekolah/ dokter kecil yang jumlahnya cukup dan 5) angka ketidakhadiran karena sakit yang rendah (Kemenkes, 2017).

Kegiatan Program Pengabdian Masyarakat ini bertujuan untuk meningkatkan pengetahuan dan perilaku siswa sekolah dasar dalam mengenal dan mencegah penularan diare serta mampu mengaplikasikannya dalam kegiatan sehari-sehari selama siswa berada di sekolah. Menurut Purnama, D., \& Witdiawati, (2018), proses pemberian informasi dan pengetahuan tentang penyakit melalui kegiatan penyuluhan dapat menjadi salah satu upaya peningkatan literasi siswa sekolah. Peran siswa 
pada kegiatan ini adalah aktif sebagai peserta penyuluhan. Luaran dari pendidikan kesehatan ini adalah terciptanya kebiasaan cuci tangan pada siswa sekolah. Adapun kriteria hasilnya adalah setidaknya setidaknya $80 \%$ siswa sekolah memiliki pengetahuan dan perilaku yang baik dalam kebiasaan cuci tangan serta pihak sekolah dapat memfasilitasi sarana cuci tangan yang sesuai dengan standar kesehatan.

Berdasarkan uraian diatas, maka kami selaku tim mengambil judul kegiatan PPM ini Edukasi Kebiasaan Cuci Tangan Pada Anak Sekolah Sebagai Upaya Menurunkan Resiko Diare Di SDN 01 Jayaraga Kecamatan Tarogong Kidul Kabupaten Garut. Kegiatan PPM ini terintegrasi dengan mata kuliah Pendidikan dan Promosi Kesehatan.

\section{Metode}

Metode pelaksanaan program pengabdian asyarakat ini diawali dengan tahap persiapan, pengusul PPM berkoordinasi dengan pihak sekolah SDN 01 Jayaraga untuk menyepakati kembali tujuan dari pelaksanaan kegiatan. Pelaksanaan kegiatan pendidikan kesehatan terhadap siswa sekolah dilaksanakan di SDN 01 Jayaraga dengan metode kegiatan ceramah tanya jawab, demonstrasi dan kuis sebagai evaluasi akhir. Evaluasi pengetahuan siswa dengan pre test dan post test saat kegiatan. Jumlah siswa yang hadir 56 orang, 2 orang guru dan 6 orang mahasiswa. Untuk tehnik cuci tangan dilakukan dengan demonstrasi secara langsung cara cuci tangan dengan metode 6 langkah. Kegiatan penyuluhan diselingi dengan acara games berupa permainan, sehingga peserta siswa tidak tampak jenuh dan kembali fokus mengikuti kegiatan.

\section{Hasil}

Pelaksanaan kegiatan mendapat apresiasi dari pihak sekolah dan para siswa. Peserta antusias mengikuti kegiatan dari awal sampai akhir. Kegiatan di hadiri oleh 56 orang siswa kelas V, 2 orang guru dan 6 orang mahasiswa. Alasan pemilihan peserta kelas $\mathrm{V}$ adalah karena tingkatan kelas $\mathrm{V}$ kedepannya bisa menjadi role model bagi adik kelasnya. Adapun karakteristik siswa yang mengikuti pendidikan kesehatan adalah sebagai berikut:

\begin{tabular}{|c|c|c|c|}
\hline No. & Variabel & $\mathbf{N}$ & Persentase (\%) \\
\hline & Usia: & & \\
\hline & 9- 10 tahun & 12 & 21,4 \\
\hline & $\geq 10-12$ tahun & 44 & 78,6 \\
\hline & Tingkatan kelas & & \\
\hline & Kelas 5 & 56 & 100 \\
\hline & Jenis kelamin & & \\
\hline & Laki-laki & 24 & 42,86 \\
\hline & Perempuan & 32 & 57,14 \\
\hline 4. & $\begin{array}{l}\text { Pekerjaan orang tua } \\
\text { Tidak bekeria }\end{array}$ & 2 & 3,6 \\
\hline
\end{tabular}




\begin{tabular}{llcc}
\hline No. & \multicolumn{1}{c}{ Variabel } & N & Persentase (\%) \\
\hline Buruh & 16 & 28,6 \\
PNS & 18 & 32,14 \\
Wiraswasta & 20 & 35,7 \\
\hline $5 . \quad$ Pernah mendapat edukasi cuci & & \\
tangan dan diare & 32 & 57,14 \\
Ya & 24 & 42,86 \\
Tidak & & \\
6. Pengalaman sakit akibat tidak & & \\
cuci tangan (diare, ispa, kholera, & & 100 \\
flu) & 56 & 0 \\
Ya & 0 & \\
Tidak & & \\
& &
\end{tabular}

Dari tabel 1, usia siswa yang mengikuti kegiatan penkes sebagian besar lebih berusia 11-12 tahun (44\%). Seluruh siswa (100\%) pernah mengalami sakit yang disebabkan oleh perilaku cuci tangan (ISPA, Diare, Kholera, Flu). Sebagian siswa $(42,86)$ belum pernah mendapatkan edukasi tentang tehnik cuci tangan yang sesuai dengan syarat kesehatan.

Kegiatan penkes diawali dengan pengukuran pengetahuan siswa pre test dan diakhiri dengan post test. Hasil pre test dan post test didistribusikan berdasarkan jumlah jawaban benar responden siswa yang mengikuti kegiatan. Adapun hasil pre dan post test dapat di lihat pada tabel 2 berikut :

Tabel 2 Distribusi Frekuensi Pengetahuan peserta siswa sebelum dan sesudah kegiatan edukasi $(\mathbf{N}=56)$

\begin{tabular}{|c|c|c|c|c|c|}
\hline \multirow[t]{2}{*}{ No } & \multirow[t]{2}{*}{ Test } & \multicolumn{2}{|c|}{ Kurang } & \multicolumn{2}{|c|}{ Baik } \\
\hline & & $\mathbf{F}$ & $\%$ & $\mathbf{F}$ & $\%$ \\
\hline 1 & Pre test & 22 & 39 & 34 & 61 \\
\hline 2 & Post test & 5 & & 51 & 91 \\
\hline & & 8,9 & & & \\
\hline
\end{tabular}

Untuk menguji perbedaan skor pengetahuan sebelum dan sesudah diberikan pendidikan masing-masing siswa di uji distribusi dengan memberikan pertanyaan dalam bentuk kuesioner (Quis). Berdasarkan hasil jawaban siswa didistribusi frekuensi dengan hasil pengetahuan sebelum penkes adalah $61 \%$ siswa berada pada kategori baik sedangkan untuk pengetahuan sesudah adalah $91 \%$ berada pada kategori baik. Pengetahuan yang dianalisis 56 orang siswa. Berdasarkan hasil distribusi frekuensi jawaban siswa, ada perbedaan pengetahuan siswa sebelum dan sesudah pendidikan kesehatan tentang mengenal dan mencegah penularan diare melalui kebiasaan cuci tangan. 


\section{Pembahasan}

Hasil kegiatan menunjukan ada perubahan dalam pengetahuan siswa tentang kebiasaan cuci tangan. Perilaku cuci tangan menjadi salah satu indikator PHBS pada anak sekolah. Kebiasaan cuci tangan merupakan salah satu upaya untuk mencegah penyakit Diare. Ada hubungan yang signifikan antara kebiasaan cuci tangan dengan insiden diare (Purwandari, R., \& Ardiana, A., 2015). Kegiatan penyuluhan yang dilakukan di SDN Jayaraga hanya merupakan salah satu stimulasi untuk mensosialisasikan PHBS, salah satunya kebiasaan cuci tangan pakai sabun. Modifikasi dalam strategi atau metode pendidikan kesehatan untuk anak sekolah sangat diperlukan. Kegiatan penyuluhan yang diselingi games, dan simulasi cuci tangan yang disertai musik dalam kegiatan PPM ini meningkatkan antusias siswa.

Hasil pre test di awal kegiatan, pengetahuan siswa tentang penyakit diare $61 \%$ sudah berada dalam kategori baik. Sehingga perlu penerapan kebijakan dari pihak sekolah agar kebiasaan cuci tangan menjadi perilaku yang dapat siswa terapkan selama di sekolah. Kontinuitas kegiatan juga menjadi hal yang sangat penting, sehingga informasi yang terus menerus kepada siswa diharapkan dapat menjadi dasar dalam perubahan perilaku PHBS cuci tangan siswa disekolah. Diharapkan edukasi kebiasaan cuci tangan dapat tersosialisasikan oleh pihak sekolah keseluruh siswa disemua tingakatan kelas.

Selain edukasi, ketersediaan fasilitas cuci tangan menjadi faktor penting dalam penatalaksanaan PHBS di sekolah. Sebagai bentuk kadeudeuh pihak Tim PKM juga memberikan contoh dispenser tempat sabun cair untuk cuci tangan kepada pihak sekolah. Tindak lanjut kegiatan PPM ini yaitu tim PPM melaporkan kepada pihak sekolah dan Puskesmas bahwa sudah dilakukan pendidikan kesehatan tentang Pendidikan dan promosi kesehatan kebiasaan cuci tangan pada anak sekolah sebagai upaya menurunkan resiko diare di SDN Jayaraga Kecamatan Tarogong Kidul Kabupaten Garut. Hal ini bertujuan untuk meningkatkan kesinambungan pembinaan dan pemantauan terutama dari pihak Puskesmas dan juga orang tua siswa. Guru mempunyai peran sangat penting dalam pengenalan dan deteksi dini masalah kesehatan pada anak sekolah. Berbagai masalah kesehatan dan penyakit pada anak sekolah yang dapat dicegah dan ditangani dengan segera jika masalah kesehatan tersebut dapat terdeteksi lebih dini (Nurhidayah, Mediani, \& Mardhiyah, 2018).

\section{Ucapan Terimakasih}

Penulis menyampaikan terimakasih kepada semua pihak yang telah membantu dalam pelaksanaan kegiatan Program Pengabdian Masyarakat ini. Secara khusus penulis ingin mengucapkan terimakasih dan penghargaan yang setinggi-tingginya kepada: Prof. Dr. Med. Tri Hanggono Achmad, dr., selaku Rektor Universitas Padjadjaran dan Hj. Henny Suzana Mediani.S.Kp.,MNg.,Ph.D. Penulis juga menyampaikan terimakasih kepada Kepala sekolah, para siswa, para guru SDN Jayaraga dan juga tim 
mahasiswa angkatan 2017 Fakultas Keperawatan Kampus Garut (Kelompok Pendidikan dan Promosi

Kesehatan Kebiasaan Cuci Tangan) atas partisipasinya dalam pelaksanaan kegiatan Program Pengabdian Masyarakat ini.

\section{Daftar Pustaka}

Depkes (2014). Infodatin CTPS. http://www.depkes.go.id/download.php?file=download/pusdatin/infodatin/infodatin-ctps.pdf.

Direktorat Promosi Kesehatan \& Pemberdayaan Masyarakat (2016). PHBS. http://promkes.kemkes.go.id/phbs.

Glanz, K., Rimer, B. K., \& Viswanath, K. (Eds.). (2008). Health behavior and health education: theory, research, and practice. John Wiley \& Sons.

Kemenkes RI (2017). Unit Kesehatan Sekolah (UKS) menjadi Transformasi dalam Upaya Kesehatan di Lingkungan Sekolah. http://www.depkes.go.id/article/view/17022800009/unit-kesehatan-sekolah-uks-menjadi-transformasi-dalam-upaya-kesehatan-dilingkungan-sekolah.html.

Kep, N. R. H. M. (2017). Hubungan Perilaku Cuci Tangan Pakai Sabun (Ctps) Di Sd 005 Dan Sd 006 Dengan Kejadian Diare Wilayahkerja Puskesmas Bangkinang Kotatahun 2014. Jurnal Ners, 5(2), 47-61.

Nurhidayah, I., Mediani, H. S., \& Mardhiyah, A. (2018). Pemberdayaan Guru Sekolah dalam Deteksi Dini Tuberkulosis pada Anak Sekolah. Media Karya Kesehatan, 1(2).

Purnama, D., \& Witdiawati, W. (2018). Literasi Penyakit HIV-AIDS pada Siswa Madrasah Tsanawiah Negeri 1 Garut. Media Karya Kesehatan, 1(1).

Purwandari, R., \& Ardiana, A. (2015). Hubungan antara perilaku mencuci tangan dengan insiden diare pada anak usia sekolah di Kabupaten Jember. Jurnal Keperawatan, 4(2). 